\title{
IMPLEMENTASI PETA KONSEP MENGGUNAKAN MODEL PEMBELAJARAN KOOPERATIF TPS SEBAGAI COGNITIVE DIAGNOSTIC ASSESSMENT (CDA)
}

\author{
Sussi Widiastuti ${ }^{1}$ \\ Leny Yuanita \\ Wasis $^{2}$ \\ ${ }^{1}$ Guru kimia SMKN 1 kediri, Mahasiswa S2 pendidikan sains pps Unesa \\ ${ }^{2}$ Dosen pendidikan sains pps Unesa \\ email: sussiwidiastuti@yahoo.co.id
}

\begin{abstract}
Abstrac: The objective this research is to implement a concept maps as a learning strategy and Cognitive Diagnostic Assessment (CDA) using TPS' Cooperative Learning Model. The subject of this research were X TITL 1, X TKJ 2, and X TKR 4 of SMK 1 Kediri on the subject of chemical reactions with One Group Pretest-Posttest design. The implementation of lesson plan is well categorized, the most dominant student activity is working in pairs, there is the changing of students' concept understanding level. The value of the correlation between the score of concept maps and learning outcomes is 0.7, it can be interpreted that the higher score in the concept map, the higher of learning outcomes. It can be concluded that concept maps can implement using TPS' cooperative learning model as a learning strategies and Cognitive Diagnostic Assessment (CDA).
\end{abstract}

Keywords: concept maps, TPS' cooperative learning model, Cognitive Diagnostic Assessment (CDA

Abstrak: Penelitian ini bertujuan mengimplementasikan peta konsep menggunakan model pembelajaran kooperatif TPS sebagai strategi belajar dan Cognitive Diagnostic Assessment (CDA). Subyek penelitian ini adalah kelas X TITL 1, X TKJ 2, dan X TKR 4 SMKN 1 Kediri pokok bahasan Reaksi Kimia dengan rancangan penelitian One Group Pretest-Posttest design. Temuan hasil penelitian yakni keterlaksanaan RPP berkategori baik, aktivitas siswa yang dominan adalah bekerja berpasangan, adanya perubahan tingkat pemahaman konsep siswa. Nilai korelasi antara skor peta konsep dan nilai hasil belajar lebih dari 0,7, dapat disimpulkan semakin tinggi skor peta konsep semakin tinggi pula nilai hasil belajar. Disimpulan bahwa peta konsep dapat diimplementasikan menggunakan model pembelajaran kooperatif TPS Cognitive Diagnostic Assessment (CDA).

Kata-kata Kunci: peta konsep, model pembelajaran kooperatif TPS, Cognitive Diagnostic Assessment (CDA)

\section{PENDAHULUAN}

Upaya meningkatkan kualitas pendidikan dapat ditempuh melalui peningkatan kualitas pembelajaran dan kualitas sistem penilaiannya. Kualitas pembelajaran dapat dilakukan melalui proses pembelajaran. Namun yang perlu disadari bahwa proses pembelajaran bukan sematamata proses penyampaian materi bidang ilmu tertentu saja, sebaliknya yang lebih penting adalah proses pengembangan kemampuan strategi belajar peserta didik. Merupakan hal yang aneh apabila kita mengharapkan siswa belajar namun jarang mengajarkan mereka tentang belajar. Sama halnya, guru kadang-kadang meminta siswa mengingat sejumlah besar bahan ajar namun jarang mengajarkan siswa seni menghafal (Nur, 2011).

Berdasarkan identifikasi penyebab persoalan yang dihadapi oleh siswa pada mata pelajaran Kimia di atas, perlu adanya strategi belajar yang dapat meningkatkan pengetahuan factual dan pengetahuan prosedural. Beberapa strategi belajar yang dimaksud adalah strategi mengulang, strategi elaborasi, strategi organisasi dan strategi metakognitif. Strategi yang diprediksikan mampu membangun dan meningkatkan pengetahuan faktual dan prosedural adalah strategi organisasi, yaitu dengan menggunakan peta konsep. Peta konsep dapat membantu peserta didik berpikir secara holistik karena peta konsep bekerja untuk memahami keterkaitan gagasan. Salah satu hasil dari representasi visual adalah fokus pada mengembangkan dan mengingat asosiasi yang relevan, bukan konsep menghafal atau dicatat dengan cara yang lebih linier.

Penilaian merupakan komponen yang sangat penting dalam penyeleggaraan pendidikan. Menurut Mardapi (2004), penilaian dan pembelajaran adalah dua kegiatan yang saling mendukung. Upaya meningkatkan kualitas pembelajaran dapat dilakukan melalui upaya perbaikan sistem penilaian. Sistem penilaian yang baik akan menghasilkan kualitas belajar yang baik. Kualitas pembelajaran ini dapat dilihat dari hasil penilaiannya, selanjutnya sistem penilaian yang baik akan mendorong pendidik untuk menentukan strategi mengajar yang baik dalam memotivasi peserta didik untuk belajar yang lebih baik (Pantar, 2009). Penilaian juga mempunyai kekuatan untuk mengarahkan apa yang diajarkan dan bagaimana mengajarkannya di sekolah (Kato, 2009), oleh karena itu 
dalam upaya peningkatan kualitas pendidikan diperlukan perbaikan sistem penilaian yang diterapkan.

Mc. Clure (1999) mensyaratkan penilaian (assessment) yang ideal adalah obyektif, dapat diandalkan, meminimalkan pengaruh konteks kalimat terhadap respon siswa, dan mampu mengungkap struktur pengetahuan siswa. Asesmen tradisional seperti pilihan ganda dan jawaban singkat mungkin saja obyektif dan dapat diandalkan, namun respon siswa dibatasi oleh konteks pada setiap item tes. Keterbatasan pada respon siswa dapat menutupi organisasi pengetahuan setiap siswa. Asesmen alternatif seperti esai, laporan, presentasi, dan penilaian proyek memungkinkan mengurangi kendala pada respon siswa serta dapat mengungkapkan struktur pengetahuan mereka, namun subyektifitasnya tinggi dikarenakan inkonsistensi skor yang diberikan oleh penilai.

Peta konsep dapat digunakan dalam pembelajaran dan sebagai asesmen. Peta konsep adalah sebuah diagram yang menunjukkan pemahaman sebuah konsep atau gagasan. Penilaian berdasarkan peta konsep mempunyai keseimbangan antara obyektivitas yang diinginkan dan sensitivitas terhadap struktur pengetahuan siswa, karena potensial mempunyai keseimbangan itulah peta konsep dapat digunakan sebagai penilaian kelas dalam dua cara. Pertama, peta konsep berguna untuk diagnosis karena peta konsep peka terhadap kesalahpahaman yang terjadi pada siswa dalam hal: (a) struktur pengetahuan siswa, (b) adanya gangguan atau distorsi dalam pemahaman konten, dan (c) kesalahan karena kelalaian. Kedua, dibandingkan dengan penilaian tradisional yang subyektif, peta konsep relatif lebih sederhana, sehingga mengurangi ancaman terhadap keakuratan penilaian (Mc. Clure, 1999; RuizPrimo, 2000).

Cognitive Diagnostic Assessment (CDA) adalah suatu jenis asesmen yang didesain untuk mengukur struktur pengetahuan siswa. CDA mampu memberikan informasi kepada guru dan pembuat kebijakan mengenai strategi siswa dalam memecahkan masalah, melihat hubungan antar konsep, dan pemahaman siswa dalam suatu domain yang pada akhirnya dapat memperbaiki pembelajaran (Jang, 2008; Leighton dan Gierl, 2007). Tujuan utama pengajaran strategi adalah mengajarkan siswa untuk belajar atas kemauan dan kemampuan diri sendiri. Novak (2008) mengatakan bahwa ketika siswa bekerja dalam kelompok kecil maka akan memperlihatkan hasil kognitif yang positif. Novak, dalam kelasnya di Universitas Cornell, menemukan bahwa membuat peta konsep dalam kelompok kecil kooperatif menghasilkan peta konsep yang luar biasa. Peta konsep yang dibuat dalam kelompok kecil memperlihatkan betapa beragamnya pemahaman tentang suatu ide. Untuk itu strategi belajar peta konsep dilatihkan kepada siswa menggunakan model pembelajaran kooperatif tipe TPS. Digunakan tipe TPS, karena memilki memiliki prosedur yang ditetapkan secara eksplisit untuk memberi siswa waktu lebih banyak untuk berpikir, menjawab, dan saling membantu satu sama lain (Slavin, 1995).

Pokok bahasan Reaksi Kimia, tepat apabila dilakukan strategi belajar dan asesmen berupa peta konsep dikarenakan dapat meningkatkan pemahaman konsep dan mendeteksi konsep-konsep yang belum dipahami siswa, sehingga siswa tidak dibiarkan maju dengan konsep-konsep yang tidak tepat, yang pada akhirnya hal tersebut dapat menimbulkan masalah- masalah belajar di masa yang akan datang. Dari latar belakang diatas maka peneliti mengangkat judul penelitian implementasi peta konsep menggunakan model pembelajaran kooperatif TPS sebagai strategi belajar dan Cognitive Diagnostic Assessment (CDA).

\section{METODE PENELITIAN}

Penelitian ini merupakan penelitian praeksperimen yang merupakan pendekatan dari eksperimen yang sesungguhnya. Menurut Fraenkel (2009) suatu penelitian disebut sebagai penelitian praeksperimen karena tidak ada pengontrolan variabel. Populasi penelitian ini adalah siswa kelas X SMKN 1 Kediri tahun pelajaran 2012/2013, sedangkan subyek penelitian yang digunakan adalah kelas X-Teknik Instalasi Tenaga Listrik 1 (X TITL 1), kelas X-Teknik Komputer dan Jaringan 2 (X TKJ 2), dan kelas X-Teknik Kendaraan Ringan 4 (X TKR 4), dengan rancangan penelitian yang digunakan adalah One Group Pretest-Posttest Design.

Tahapan penelitian ini dibagi menjadi dua tahap yaitu tahap pengembangan perangkat pembelajaran dan tahap implementasi perangkat pembelajaran yang telah dikembangkan. Teknik pengumpulan data yang digunakan dalam penelitian ini adalah: 1) observasi, digunakan untuk mengumpulkan data penelitian tentang keterlaksanaan pembelajaran, aktivitas siswa saat pembelajaran, dan kendala yang dihadapi, 2) pemberian tes, terdiri atas: a) tes diagnostik (pretest dan posttest), digunakan untuk mengetahui tingkat pemahaman konsep siswa sebelum dan setelah kegiatan pembelajaran. Tes diagnostik ini juga digunakan untuk membuat profil peta konsep siswa, c) tes hasil belajar, digunakan untuk mengetahui hasil belajar siswa pada materi Reaksi Kimia dengan strategi peta konsep menggunakan model pembelajaran kooperatif tipe TPS. Tes hasil belajar berupa tes uraian dan peta konsep dengan format fill-in- the-map (mengisi ke dalam peta). Tes hasil belajar yang sama (tes uraian tanpa peta konsep) digunakan untuk mengetahui korelasi antara skor peta konsep dan nilai hasil belajar, d) pemberian tes kinerja, tes kinerja ini digunakan untuk menggali informasi 
keterampilan siswa dalam membuat peta konsep, 3) penyebaran angket, angket digunakan untuk mendapatkan informasi tentang respon siswa terhadap peta konsep sebagai strategi belajar dan alat evaluasi/CDA.

Teknik analisis data yang digunakan dalam penelitian ini adalah: 1) uji t-berpasangan untuk mengetahui adanya perbedaan keterampilan siswa dalam membuat peta konsep dan tingkat pemahaman konsep siswa yang meliputi ukuran struktur konsep dan kekuatan struktur konsep pada saat pretest dan posttest, 2) korelasi Pearson product moment correlation ( $r$ ) untuk mengetahui keefektifan peta konsep sebagai CDA.

\section{HASIL PENELITIAN DAN PEMBAHASAN}

Peta konsep dapat digunakan sebagai strategi belajar dan sebagai asesmen. Upaya untuk menggunakan peta konsep sebagai strategi belajar dapat dilakukan dengan menggunakan model pembelajaran kooperatif TPS. Hal ini dapat dilihat dari hasil pengamatan keterlaksanaan Rencana Pelaksanaan Pembelajaran (RPP) selama pertemuan 1, 2, dan 3 pada kelas X TITL 1, X TKJ 2, dan X TKR 4 yang meliputi pendahuluan, kegiatan inti, penutup, dan pengelolaan waktu menunjukkan kategori sangat baik dan persentase reliabilitas pengamatan setiap pertemuan diatas $75 \%$.

Hal ini menunjukkan bahwa RPP dengan strategi peta konsep yang dilaksanakan dalam pembelajaran
Kooperatif TPS dapat digunakan untuk melatihkan membuat peta konsep. Novak (2008) mengatakan bahwa ketika siswa bekerja dalam kelompok kecil maka akanmemperlihatkan hasil kognitif yang positif. Novak, dalam kelasnya di Universitas Cornell, menemukan bahwa membuat peta konsep dalam kelompok kecil kooperatif menghasilkan peta konsep yang luar biasa. Peta konsep yang dibuat dalam kelompok kecil memperlihatkan betapa beragamnya pemahaman tentang suatu ide.

Peta konsep dilatihkan kepada siswa selama tiga kali pertemuan. Kemampuan keterampilan siswa dalam membuat peta konsep mengalami peningkatan, yang meliputi keterampilan mengidentifikasi konsep, penempatan hierarki, menggunakan arah panah untuk menggambarkan arah suatu ide, kelogisan koneksi antarkonsep, penggunaan kata hubung, pencantuman ikatan silang dan contoh, serta kerapian dan pengorganisasian. Hal ini sejalan dengan pendapat Novak (2008) bahwa diperlukan latihan dalam membuat peta konsep, artinya siswa perlu terus berlatih agar peta konsep yang dibuatnya tidak tampak berantakan dan mempunyai organisasi konsep yang rapi, sehingga mampu menampilkan struktur kognitif siswa dengan lebih baik. Data hasil keterampilan siswa dalam membuat peta konsep dapat dilihat pada Tabel 2.

Tabel 2 Keterampilan Siswa Membuat Peta Konsep:

\begin{tabular}{|c|c|c|c|c|c|c|c|}
\hline \multirow{3}{*}{ No } & \multirow{3}{*}{ Aspek yang Dinilai } & \multicolumn{2}{|c|}{ TITL 1} & \multicolumn{2}{|c|}{ TKJ 2} & \multicolumn{2}{|c|}{ TKR 4} \\
\hline & & \multicolumn{2}{|c|}{ Rata-rata Skor } & \multicolumn{2}{|c|}{ Rata-rata Skor } & \multicolumn{2}{|c|}{ Rata-rata Skor } \\
\hline & & Pretest & Posttest & Pretest & Posttest & Pretest & Posttest \\
\hline 1 & engidentifikasi konsep & 1,74 & 3,58 & 1,71 & 3,52 & 1,90 & 2,87 \\
\hline 2 & mlah hierarki & 2,35 & 3,45 & 2,58 & 3,19 & 2,58 & 3,48 \\
\hline 3 & $\begin{array}{l}\text { enggunakan arah anak panah untuk } \\
\text { enggambarkan arah suatu ide }\end{array}$ & 1,22 & 3,10 & 2,19 & 3,68 & 2,10 & 3,61 \\
\hline 4 & pneksi antarkonsep adalah logis & 1,06 & 3,13 & 1,58 & 3,48 & 1,74 & 3,49 \\
\hline 5 & enggunakan kata hubung & 1,32 & 3,13 & 1,55 & 3,29 & 1,77 & 3,49 \\
\hline 6 & ncantuman ikatan silang & 1,00 & 1,19 & 1,00 & 1,26 & 1,00 & 1,10 \\
\hline 7 & ncantuman contoh & 1,16 & 2,06 & 1,00 & 3,16 & 1,74 & 1,52 \\
\hline 8 & rapian dan pengorganisasian & 1,39 & 3,06 & 1,23 & 3,29 & 1,65 & 3,45 \\
\hline \multirow{2}{*}{\multicolumn{2}{|c|}{ 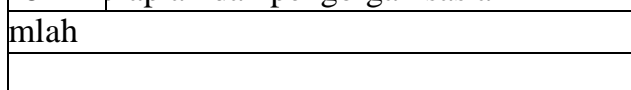 }} & 11,24 & 22,70 & 12,84 & 24,87 & 14,48 & 24,87 \\
\hline & & 22,70 & 73,23 & 41,42 & 80,23 & 46,71 & 74,23 \\
\hline
\end{tabular}

Tabel 2 menunjukkan bahwa keterampilan siswa kelas X TITL 1 meningkat dari $22,70 \%$ menjadi $73,23 \%$, kelas X TKJ 2 meningkat dari 41,42\% menjadi 80,23\%, dan kelas X TKR 4 meningkat dari $46,71 \%$ menjadi $74,23 \%$. Untuk mengetahui perbedaan keterampilan siswa membuat peta konsep sebelum dan setelah memperoleh strategi peta konsep digunakan uji t-berpasangan.
Tabel 3 Uji t-berpasangan pada Keterampilan Membuat Peta Konsep Siswa

Berdasarkan pada Tabel 3 nilai $\mathrm{t}$ dengan derajat bebas 30 untuk kelas X TITL 1 adalah -6,285, untuk kelas X TKJ 2 adalah -6,109, dan untuk kelas X TKR 4 adalah 3,868. Dikarenakan thit < ttabel 1,70 maka H0 ditolak, sehingga dapat disimpulkan bahwa keterampilan siswa

\begin{tabular}{|l|c|l|c|c|c|c|c|}
\hline & \multicolumn{2}{|c|}{ X TITL 1 } & \multicolumn{2}{c|}{ X TKJ 2 } & \multicolumn{2}{c|}{ X TKR 4 } & \multirow{2}{*}{ Keterangan } \\
\cline { 2 - 6 } & $\mathrm{t}_{\text {hit }}$ & $\mathrm{df}$ & $\mathrm{t}_{\text {hit }}$ & $\mathrm{df}$ & $\mathrm{t}_{\text {hit }}$ & $\mathrm{df}$ & \\
\hline etest-Posttest & $-6,285$ & 30 & $-6,109$ & 30 & $-3,868$ & 30 & $\mathrm{t}_{\text {hit }}<\mathrm{t}_{\text {tabel }} 1,70$ maka $_{0}$ ditolak \\
\hline
\end{tabular}


membuat peta konsep pada saat pretest dan posttest berbeda secara signifikan. Dengan kata lain strategi belajar peta konsep meningkatkan keterampilan membuat peta konsep siswa kelas X TITL, kelas X TKJ 2, dan X TKR 4.

Peningkatan keterampilan siswa dalam membuat peta konsep didukung oleh respon siswa yang baik terhadap penggunaan peta konsep sebagai strategi belajar serta ditunjukkan oleh aktivitas siswa selama pembelajaran, dengan aktivitas yang dominan adalah menemukan konsep lain yang berhubungan dengan konsep utama, mengerjakan LKS, dan bekerja sama.
Strategi belajar peta konsep mampu meningkatkan pemahaman konsep siswa. Pemahaman konsep adalah ukuran dan kekuatan struktur konsep siswa. Ukuran struktur adalah jumlah konsep yang dibuat siswa dibandingkan dengan jumlah konsep yang dibuat guru, sedangkan kekuatan struktur adalah koneksi antarkonsep sahih yang dibuat siswa, yaitu jumlah koneksi sahih yang dibuat oleh siswa dibandingkan dengan jumlah koneksi sahih yang dibuat oleh guru.

Tabel 4 Uji t-berpasangan pada Ukuran Struktur Peta Konsep Siswa:

\begin{tabular}{|l|c|l|l|l|l|l|l|}
\hline & \multicolumn{2}{|c|}{ X TITL 1 } & \multicolumn{2}{|c|}{ X TKJ 2 } & \multicolumn{2}{c|}{ X TKR 4 } & \multirow{2}{*}{ Keterangan } \\
\cline { 2 - 6 } & $\mathrm{t}_{\text {hit }}$ & $\mathrm{df}$ & $\mathrm{t}_{\mathrm{hit}}$ & $\mathrm{df}$ & $\mathrm{t}_{\text {hit }}$ & $\mathrm{df}$ & \\
\hline etest-Posttest & $-11,676$ & 30 & $-6,584$ & 30 & $-4,183$ & 30 & $<\mathrm{t}_{\text {tabel }} 1,70$ maka $_{0}$ ditolak \\
\hline
\end{tabular}

Berdasarkan pada Tabel 4 nilai t dengan derajat bebas 30 untuk kelas X TITL 1, X TKJ 2, dan X TKR 4 adalah $-11,676,-6,584$, dan $-4,183$. Dikarenakan thit < ttabel 1,70 maka H0 ditolak, sehingga dapat- disimpulkan bahwa ukuran struktur pada saat pretest dan posttest berbeda secara signifikan, dengan kata lain strategi belajar peta konsep meningkatkan ukuran struktur siswa kelas X TITL 1, X TKJ 2, dan X TKR 4.

Tabel 5 Uji t-berpasangan pada Kekuatan Struktur Peta Konsep Siswa

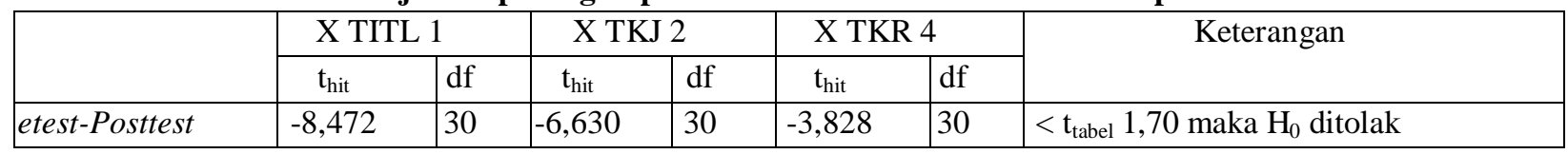

Berdasarkan pada Tabel 5 nilai $\mathrm{t}$ dengan derajat bebas 30 untuk kelas X TITL 1, X TKJ 2, dan X TKR 4 adalah 8,$472 ;-6,630$; dan $-3,828$, dikarenakan thit $<$ ttabel 1,70 maka $\mathrm{H0}$ ditolak, sehingga dapat disimpulkan struktur yang dibuat pada saat pretest dan posttest berbeda secara signifikan, dengan kata lain strategi belajar peta konsep meningkatkan kekuatan struktur konsep siswa kelas $\mathrm{X}$ TITL 1, X TKJ 2, dan X TKR 4.

Tingkat pemahaman konsep adalah kemampuan mengintegrasi beberapa konsep yang dapat diukur dari skor yang diperoleh siswa dalam membuat peta konsep yang dinyatakan dengan empat kategori tingkat pemahaman konsep menurut Lomask, yaitu sistem penilaian dengan beberapa cara menganalisis dan mengevaluasi jawaban siswa, meliputi ukuran (jumlah konsep) dan kekuatan (koneksi), kemudian dicocokkan dengan tabel tingkat pemahaman konsep. Terdapat empat tingkat pemahaman konsep yaitu: a) tingkat pemahaman konsep nominal berarti siswa hanya mampu mengenali suatu istilah dari namanya tanpa menghubungkan dengan konsep sentral, b) pemahaman konsep tingkat fungsional yaitu siswa mampu mengingat definisi yang tepat mengenai suatu konsep tanpa memahami, c) pemahaman konsep tingkat struktural adalah siswa mampu membangun hubungan antar konsep, dan d) pemahaman konsep tingkat multidimensional yaitu siswa mampu menerapkan dan mengintegrasi pengetahuan beberapa konsep.

Tabel 6 Tingkat Pemahaman Konsep Siswa

\begin{tabular}{|l|c|c|c|c|c|c|}
\hline \multirow{3}{*}{$\begin{array}{c}\text { ingkat Pemahaman } \\
\text { Konsep }\end{array}$} & \multicolumn{2}{|c|}{ X TITL 1 } & \multicolumn{2}{c|}{ X TKJ 2 } & \multicolumn{2}{c|}{ X TKR 4 } \\
\cline { 2 - 7 } & \multicolumn{2}{c|}{ umlah siswa (\%) } & Jumlah siswa (\%) & umlah siswa (\%) \\
\cline { 2 - 7 } & Pretest & Posttest & Pretest & Posttest & Pretest & Posttest \\
\hline pminal & 70,97 & - & 51,61 & - & 54,84 & 6,45 \\
\hline ngsional & 9,68 & 6,45 & 22,58 & - & 25,81 & 22,58 \\
\hline ruktural & 19,35 & 16,13 & 25,81 & 19,35 & 16,13 & 25,81 \\
\hline ultidimensional & - & 77,42 & - & 80,65 & 3,23 & 45,16 \\
\hline
\end{tabular}

Tabel 6 menunjukkan bahwa pada saat pretest siswa kelas X TITL 1, X TKJ 2, dan X TKR 4 yang berada pada tingkat pemahaman konsep nominal sebanyak 70,97\%; $51,61 \%$; dan 54,85\%. Siswa yang berada pada tahap 
fungsional adalah $9,68 \% ; 22,58$; dan $25,81 \%$, siswa yang berada pada tahap struktural adalah $19,35 \%$; 25,81\%; dan $16,13 \%$. Tingkat pemahaman konsep multidimensional hanya dimiliki oleh iswa kelas X TKR 4 (3,23\%). Pada saat posttest siswa yang berada pada tingkat pemahaman konsep nominal hanya terdapat pada siswa kelas X TKR $4(6,45 \%)$, tingkat pemahaman konsep fungsional dimiliki siswa X TITL 1 dan X TKR 4 (6,45\% dan $22,58 \%$ ). Siswa yang berada pada tahap struktural terdapat pada semua kelas dengan jumlah siswa $16,13 \%$ (X TITL 1), 19,35\% (X TKJ 2), dan 25,81\% (X TKR 4), sedangkan siswa yang mempunyai tingkat pemahaman konsep multidimensional sebesar 77,42\% (X TITL 1), $80,65 \%$ (X TKJ 2), 45,16\% (X TKR 4).

Sebagaimana yang dikemukakan oleh Vanides et al (2005) bahwa penggunaan peta konsep dapat mengungkapkan tingkat pemahaman konsep siswa. Hal ini dikarenakan proses konstruksi siswa nampak pada saat membuat peta konsep. Pada saat membuat peta konsep, siswa dituntut untuk melakukan proses subsumption, diferensiasi progresif, dan rekonsiliasi integratif (Novak, 2008). Pada saat proses subsumption, siswa diharuskan mampu memilah konsep berdasarkan hierarkinya. Konsep yang utama diletakkan pada bagian atas, selanjutnya konsep yang umum dan kurang umum berada di bawahnya. Pada proses kedua, diferensiasi progresif, terjadi pengembangan dan elaborasi konsep-konsep yang tersubsumsi, artinya proses yang terjadi terus menerus dimana konsep yang baru memperoleh makna yang lebih luas. Pada akhirnya, suatu konsep tidak pernah "finally learned", tetapi selalu berkembang, mengalami modifikasi, dan membuatnya lebih eksplisif dan lebih inklusif. Proses yang ketiga yaitu rekonsiliasi integratif. Pada proses ini siswa harus mampu mengenali hubungan baru antara konsep-konsep yang terhubung. Ketika siswa memperoleh konsep baru, siswa harus mampu membandingkan dan mempertentangkan dengan konsep-konsep sebelumnya yang lebih sempit dan bagaimana konsep-konsep yang tingkatnya lebih tinggi sekarang mengambil arti baru. Konstruksi peta konsep yang dibuat siswa semakin baik dengan berlatih membuat peta konsep. Plummer (2008) mengatakan bahwa dengan berlatih membuat peta konsep, organisasi dan kejelasan koneksi konsep akan meningkat.

Penggunaan peta konsep sebagai Cognitive Diagnostic Assessment (CDA) terbukti efektif. Hal ini ditunjukkan oleh nilai korelasi antara skor peta konsep dan nilai hasil belajar lebih dari 0,7. Nilai tersebut dapat dimaknai bahwa semakin tinggi skor peta konsep semakin tinggi pula nilai hasil belajar. Efektivitas tersebut juga didukung oleh kemampuan peta konsep yang mampu mendiagnosa konsep-konsep yang kurang dipahami siswa melalui proposisi yang tidak sahih, hierarki yang tidak tepat, tidak adanya ikatan silang, dan contoh. Hal tersebut direpresentasikan dengan skor peta konsep menurut penskoran Novak, ternyata siswa yang hasil belajarnya rendah (nilai hasil belajar di bawah KKM, yaitu siswa L101R; L102R, L103R, R401R, dan R402R) hanya mampu membuat proposisi dan hierarki kurang dari $50 \%$ proposisi dan hierarki yang dibuat guru.

Proposisi tak bermakna banyak dijumpai pada siswa kelompok rendah pada semua kelas. Proposisi tak bermakna yang dijumpai terdapat pada hubungan konsepkonsep: reaksi asam basa terdiri atas asam dan basa, reaksi asam basa meliputi asam, basa, dan netral, reaksi kimia terdiri atas produk dan reaktan, koefisien reaksi dinyatakan dengan partikel reaksi, reaksi kimia didefinisikan dengan reaksi asam basa dan redoks, reaksi asam basa dibagi menjadi asam dan basa. Kata hubung memegang peranan penting dalam mengaitkan 2 konsep membentuk proposisi. Dua konsep yang dihubungkan oleh kata hubung yang berbeda dapat menghasilkan 2 proposisi yang berbeda. Hal ini didukung oleh Novak (2006) bahwa dengan melihat proposisi yang tidak tepat antara 2 konsep maka dapat dikatakan terjadi miskonsepsi. Vanides, et al. 2005 telah menggunakan peta konsep dalam kelas sains dan menemukan bahwa kata hubung yang digunakan siswa memperlihatkan kualitas proposisi yang dimiliki siswa, pada akhirnya proposisi tersebut mampu mengungkapkan miskonsepsi yang terjadi pada siswa.

Kedalaman pemahaman konsep diketahui dengan melakukan analisis terhadap komponen hierarki konsep. Pada saat posttest rata-rata jumlah hierarki maksimum yang dikemukakan oleh siswa kelompok sedang dan tinggi lebih besar daripada kelompok rendah. Hal ini menunjukkan bahwa kelompok sedang dan tinggi memiliki pemahaman yang lebih dalam dibandingkan kelompok rendah. Hal ini dikatakan Novak (2006) dalam bukunya Learning How to Learn bahwa pada waktu membuat hierarki seorang siswa harus memperhatikan konsep mana yang paling inklusif dan kurang inklusif. Hal ini membutuhkan berpikir kognitf aktif. Artinya siswa harus secara aktif mengintegrasikan pengetahuan baru yang diperoleh dalam struktur kognitif mereka. Dalam banyak pelajaran di sekolah, siswa mungkin memperoleh makna dari pengetahuan baru namun mereka tidak mempunyai kebermaknaan dari pengetahuan yang diperoleh karena siswa tidak aktif mengintegrasikannya pada kerangka konseptual yang mereka miliki. Dapat dikatakan bahwa siswa mengetahui "meaning" namun tidak "meaningfull".

Ikatan silang hanya hanya muncul pada siswa kelompok tinggi kelas X TITL 1 dan X TKJ $2(0,25 \%)$, sedangkan pada kelas X TKR $4(0,13 \%)$. Ikatan silang hanya muncul pada siswa dengan kategori tinggi, hal ini dapat dipahami, karena menurut Novak (2006) 
kemampuan untuk mencari dan mengkarakterisasi ikatan silang membutuhkan daya kreativitas yang cukup tinggi, sehingga hanya siswa yang mempunyai integrasi konsep yang baik yang dapat membuat ikatan silang. Hal ini juga didukung dengan kenyataan di lapangan bahwa kendala yang dihadapi guru adalah siswa kesulitan membuat ikatan silang dan $100 \%$ siswa menganggap membuat ikatan silang adalah sulit. Penutup

Implementasi peta konsep menggunakan model pembelajaran kooperatif TPS sebagai strategi belajar terbukti berhasil. Hal ini ditunjukkan dari adanya perubahan yang signifikan pada keterampilan siswa dalam membuat peta konsep antara sebelum dan setelah pembelajaran. Perubahan yang signifikan tersebut didukung oleh keterlaksanaan RPP yang mempunyai reliabilitas lebih dari $75 \%$. Selain itu juga ditunjukkan oleh aktivitas siswa dalam pembelajaran yang tertinggi pada pertemuan I adalah menemukan konsep lain yang berhubungan dengan konsep utama, sedangkan pada pertemuan II dan III adalah bekerja berpasangan dan mengerjakan LKS. Respon siswa yang bagus terhadap penggunaan peta konsep sebagai strategi belajar dan sebagai alat evaluasi (CDA) turut memberikan andil terhadap perubahan keterampilan siswa dalam membuat peta konsep.

Implementasi peta konsep menggunakan model pembelajaran kooperatif TPS sebagai Cognitive Diagnostic Assessment (CDA) terbukti efektif. Hal ini ditunjukkan oleh nilai korelasi antara skor peta konsep dan nilai hasil belajar lebih dari 0,7. Nilai tersebut dapat dimaknai bahwa semakin tinggi skor peta konsep semakin tinggi pula nilai hasil belajar. Efektivitas tersebut juga didukung oleh kemampuan peta konsep yang mampu mendiagnosa konsep-konsep yang kurang dipahami siswa melalui proposisi yang tidak sahih, hierarki yang tidak tepat, tidak adanya ikatan silang dan contoh. Namun dijumpai bahwa membuat ikatan silang merupakan hal yang paling dirasakan sulit oleh siswa.

\section{DAFTAR PUSTAKA}

Gierl. Mark, J., Leighton J. P., Hunka S. M. (Eds). 2007. Why Cognitive Diagnostic Assessment? Cognitive Diagnostic Assessment for Education. 1st edition. Cambridge: Cambridge University Press.

Jang. E. E. (Eds). 2008. A Framework for Cognitive Diagnostic Assessment Towards Adaptive CALL: Natural Language Processing for Diagnostic Language Assessment. 117-131. Ames, IA: Iowa State University.

Mardapi, Djemari. 2004. Penyusunan Tes Hasil Belajar. Yogyakarta: UNY

McClure, J. E., Sonak, Brian, Suen, H. 1999. "Concept
Map Assessment of Classroom Learning: Reliability, Validity and Logistical Practicality". Journal of Research in Science Teaching. 36(4), 475-492.

Novak, J.D. and Gowin, D.B. 2006. Learning How to Learn. 21st. Cambridge, England: Cambridge University Press.

Novak, J. D. 2008. Concept Maps: What the Heck is This? Novak's cmap home. Cornell University.

Nur, Mohammad. 2008. Pembelajaran Kooperatif. Cetakan kedua. Surabaya: Pusat Sains dan Matematika Sekolah UNESA

Nur, Mohammad. 2011. Strategi-Strategi Belajar. Cetakan kelima. Surabaya: Pusat Sains dan Matematika Sekolah UNESA

Pantar, FH. 2009. "Peranan Penilaian dalam Pendidikan". Makalah Asesmen Pendidikan.

Ruiz-Primo. 2000. "On The Use of Concept Maps as An Assessment Tool in Science”. Revista Electronica de Investigation Educativa. Universidad Autonoma de Baja California. Ensenada Mexico. 2(1), 29-53

Slavin, Robert. E. 1995. Cooperative Learning. Theory, Research and Practice. Boston: Allyn and Bacon.

Vanides, Jim, Yin, Yue, Tomita, Miki, Ruiz-Primo, Maria Araceli. 2005. "Using Concept Map in The Science Classroom". National Science Teachers Association. 28 (8): $27-31$. 